to remain firm after ripening — which captured attention, especially when the iconic Campbell Soup Company invested in its development. Like many at the time, Campbell's was fascinated by the promise that tomatoes could be ripened on

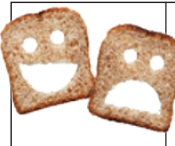
A Nature special issue nature.com/gmcrops GM CROPS:PROMISE \& REALITY

impacts, have frequently prevented approval and adoption of the crops, especially in Europe, where protesters have destroyed experiments. The United States, the world's most active user of GM crops, has seen renewed backlash as the vine to accentuate their flavour and still make the trip to the supermarket and the dinner table without turning to mush.

In early 1992, analysts predicted regulatory approval for the GM tomato within a month, and a market of at least US $\$ 500$ million a year. But less than a decade after their birth, GM crops were already facing a difficult adolescence. What was once deemed biological wizardry was increasingly being labelled Frankenfood. Consumers in Europe were bristling at the aggressive marketing of GM giant Monsanto, based in St Louis, Missouri. The Flavr Savr suffered more than a year of delays at the US Food and Drug Administration, and Campbell's began to state that it had no intention of putting the tomatoes in its soups without approval from the public. What had gone wrong? According to one analyst quoted at the time, the biotech sector had failed to prepare consumers appropriately: "Now, they realize that they have to be articulate and educate an uninformed public."

The Flavr Savr was approved in 1994 but never took off commercially. In the meantime, the biotech industry had shifted much of its attention to traits that aimed not to delight consumers, but rather to increase farm yields. Herbicide-tolerant and pest-resistant crops proliferated in the United States and more than two dozen other countries. GM organisms were to become agricultural tools.

In many places where they are planted, these GM crops have replaced conventional planting almost entirely. Yields and profits have increased, farmers have been generally happy to adopt the transgenic seeds and the technology has even made good on some of its promises to help the environment by reducing the amount and variety of pesticides needed.

GM crops, of course, still face a public-relations problem. Fears of the unfamiliar and 'unnatural', and concerns about health or environmental calls grow for foods with GM ingredients to be clearly labelled.

The analyst who spoke of an uninformed public may have been correct in 1993, but such a claim no longer applies. People are positively swimming in information about GM technologies. Much of it is wrong - on both sides of the debate. But a lot of this incorrect information is sophisticated, backed by legitimate-sounding research and written with certitude. (With GM crops, a good gauge of a statement's fallacy is the conviction with which it is delivered.)

Armed with misinformation, debaters have taken to the streets, the people as the food they eat and give to their children, those who play to the fears, concerns and uncertainty surrounding GM crops often seem to have the upper hand. And the fears are entwined with mistrust of the seed companies. Supporting GM crops can seem a thankless job: it is worthwhile to stand up for good science and the promise that it holds, but defending profit-hungry corporations feels less rewarding.

Still, there is reason to stand up for the continued use and development of GM crops. Genetic modification is a nascent technology for which development has moved very quickly to commercialization. That has forced most research into the for-profit sector. Without broader research programmes outside the seed industry, developments will continue to be profit-driven, limiting the chance for many of the advances that were promised 30 years ago - such as feeding the planet's burgeoning population sustainably, reducing the environmental footprint of farming and delivering products that amaze and delight. Transgenic technologies are by no means the only way to achieve these aims, but the speed and precision that they offer over traditional breeding techniques made them indispensable 30 years ago. They still are today. supermarkets and social media. With a topic as sensitive and dear to

\section{Freed speech}

The reform of English libel law is a victory, even if it doesn't achieve everything that was hoped.

$\mathrm{I}$ n a typically British piece of formal pomp, the speaker of the UK House of Commons, John Bercow, last week declared: "I have to acquaint the House that the House has been to the House of Peers, where a Commission under the Great Seal was read, authorizing the Royal Assent to the following Acts."

In the list of new legislation that followed, alongside the 'Marine Navigation (No. 2) Act' and the 'Groceries Code Adjudicator Act', Bercow announced the Queen's formal approval of a long-awaited reform to libel laws in England and Wales.

Nature was taken to court under the previous version of these laws, which were widely regarded as skewed in favour of those who claim libel, and we were among the many supporters of the Libel Reform Campaign, which drove the fight for change. Cases such as that of science writer Simon Singh, who was forced to defend himself against a claim by the British Chiropractic Association over an article published in the Guardian newspaper in 2008, galvanized the public and raised concern about the laws' chilling effects on the free expression of scientific opinion.

Those cases ended in victories for Singh, for Nature and for scientific debate and free speech. But it was rightly feared that those without the resources of Nature or the tenacity of Singh would back down rather than face the costs of going to court, or might even shy away from making statements that might attract attention from litigious parties in the first place.

The new law will require that bodies that trade for profit show "serious financial loss" if they wish to sue someone for defamation. It also includes formalized defences for journalists publishing on matters of public interest, and further protections for the reporting of statements made in peer-reviewed journals and at international conferences.

'Libel tourism' - in which those with no real link to Britain come to use the unfair laws in London courts - will be restricted by the new act. It sets bars for action against people who do not live in the United Kingdom or the rest of Europe, unless the claimant can show that England is truly the most appropriate venue for legal action.

These are all real gains that should improve the communication of science by making it easier to speak truths that some may not wish to hear.

The rewriting of the law led to celebration among the scientists, journalists, lawyers and others who have pushed for reform. But there were cautionary voices. It is not yet clear how the new law will work in practice for much of the Internet. And it may not reduce the cost of litigation. If defending an action is still financially crippling, concerns that the law can be used to threaten people into silence will persist.

Robert Dougans, solicitor-advocate at the litigation firm Bryan Cave in London, who represented Simon Singh in his fight with the British Chiropractic Association, said, "Frankly, I cannot see this having made any difference in any case I have been involved in, and I wish an opportunity had been taken to re-think defamation law ab initio." (See Nature http://doi.org/mc6; 2013.)
DNATURE.COM To comment online, click on Editorials at: go.nature.com/xhunqu
Dougans may be too pessimistic. There is good reason for those who have fought hard to rejoice. But it remains to be tested whether the culture of suppression has truly been swept away. If it has not, the fight will have to begin again. 